\title{
The Origin, Theory and Construction of Museum Economy Research
}

\author{
Mei Xie \\ School of Political Science and Public Administration \\ Center for Digitalized Culture and Media \\ University of Electronic Science and Technology of China \\ Chengdu, China 611731
}

\author{
Delong Gao \\ School of Political Science and Public Administration \\ Center for Digitalized Culture and Media \\ University of Electronic Science and Technology of China \\ Chengdu, China 611731
}

\begin{abstract}
Museum economy is an important part of heritage economy. It is an important part of cultural industry. Also, it is an important part of interdisciplinary research. With the rapid development of cultural industry, the museum as an important storage carrier of cultural and educational resources is more concerned. It has many researches on the development and utilization of museum cultural resources. On the other hand, the discussion on commercialization of cultural and educational resources is becoming more and more intense. And the practical needs and theoretical value of museum economic research are becoming more and more prominent. This paper analyzes the meaning, development process and main research contents of the museum economy at home and abroad. And it has also made comparison on the differences in the perspectives of museum economic research, the theory and the construction at home and abroad. And it is helpful to develop the museum economy of China and learn from the foreign research experience. To understand the museum economic research is of great significance.
\end{abstract}

Keywords-museum economy; comment; theory comparison; construction

\section{INTRODUCTION}

Museum economic research is an important part of heritage economics. And it has also made discussion on the transformation and utilization of cultural and educational resources in market economy environment. Museum is an important carrier to store cultural and educational resources. The cultural tourism resource carried by the museum has important cultural value and economic value. In addition, due to the human sharing and historical succession of cultural tourism resources, the publicity and public welfare of museum are often opposed to the economic development of museum in the practice. For the discussion on the concept of the museum economy, scholars at home and abroad have different views. The connotation and definition of the museum economy is still in the stage of discussion.

\section{DisCUSSION ON THE MEANING OF THE MUSEUM ECONOMY AT HOME AND ABROAD}

There are many interpretations of the meaning of the museum economy in foreign countries. In Kevin Moore's Museum Management, it has put forward four dimensions of the museum economy. And the museum economic research is mainly on the museum management, heritage economy and tourism industry under the comprehensive consideration. These four concepts are strategic management (including policy development, planning and performance assessment), human resources management, museum financial management and the extreme importance marketing. [1] Peter Johnson and Barry Thomas points out in the article "A Research Vision: Museum Economy" that the museum economy is clearly on the economic understanding and value assessment of the operation and activities of the museum, and the museum can be regarded as a production unit- the company. To achieve a specific goal, the museum can make the conversion operation through the production technology and the mixed use value. In the museum economy, it should pay attention to the relationship between the market capital (public and private) and visitors. And it should pay attention to economic policy issues of the museum. Also, it should highlight the mixed use value of museum, such as comprehensive output rate of protection, education, entertainment, shopping, digital display and other concepts of the museum [2]. Kenneth Hudson analyzes the necessary reasons for the commercialization of the museum in the article "The rejection of museum to stop". And the improvement of social cultural facilities, the improvement of cultural consume demands, the professional development of museum work, the marketization of museum funding sources have no longer relied on public funds [3]. Haier Buren and Gray have explained the economy of the art museum in his book "Art and Culture Economics" in details. In fact, it has expressed and conveyed historical and cultural heritage. And the museum is affirmed as the storage. At the same time, it is also suggested that all museums are always faced with the same problem. For example, it has explained the ways of allocating resources in multiple functions. It also has explained the ways of managing investment portfolio (including the fine art). And it has explained the ways of payment in investment portfolio. [4] In addition, it has studied the composition of the painting market: the primary market and the secondary market. And it also put forwards an idea that the cost of the museum is decreasing from the art demand and art supply.

The research on the economic theory of the museum started in 1990s. It wanted to achieve the modernization of museum in the museum management from the economic 
theory. In the "On the Museum Economics", Liu Hong put forward the contents of the museum economics research on the basis of the necessity of the museum economics. It mainly includes 8 economic issues. And it is mainly on the economic issues in the management of the museum business. And it also has explained a series of economic issues in the contemporary management and other works of the museum. [5] In the article "A preliminary exploration of the museum economy", Zeng Guangqing has distinguished the macro research from the micro research of museum economics. In the macro aspect, it is mainly on the relationships among the museum business, economic policy and tourism. It focuses on the museum macro income and distribution issues. In the micro aspect, it is mainly on the relationship between business expenditure and operating revenue. It pays attention to commercial revenue of the museum and the balance of social functions [6]. With the continuous development of the market economy, the number of museum has been increasing. At the same time, economic problems have become a hot issue in the development of museum. In the article "Analysis on museum economic", considering the concept of the museum economy clearly, Tian Yanping has put forward that the museum is not an enterprise, and it can't maximize the profit as the goal. The museum seeks economic benefits with the regulation of market competition. And it is mainly limited to the functions and nature of the museum. It is easy to move the concept of economics in the field of production to the non-production field. However, it is not possible to apply it. If it is applicable, it needn't to establish the economics of non-production areas. The economics of Soviet Union in non-productive areas can't be completely copied. It is the outcome of the planned economy era to call for the establishment of complete value in line with China's actual museum economics [7].

At home and abroad, there are different views on the museum economic research. However, the museum economic value is consensus. They recognize that the museum has non-material production elements as a carrier of cultural tourism resources. It has quoted Li Zuojun's article "The discussion on theory and practice of museum economics". The world's largest Chinese management encyclopedia MBA has made the definition of the museum economy. And the museum economy is based on museum or museum groups. Through the full play of the museum's unique advantages and economic value, it is an economic form of organic integration of the museum and tourism, culture and other industries. And it can promote regional soft power and economic sustainable development. Also, it is a regional economy development model to promote the development of the museum [8].

\section{The DeVelopment Stage OF THE Museum ECONOMY AT HOME AND ABROAD}

At the beginning of the museum, it is established on the basis of public welfare and publicity. In the development of museum, the museum as "No profit" social open service agencies has been the benchmarks of the museums of countries in the world. However, it lacks care for the economic operation of the museum.
The development of American museum economics can be divided into three stages. Before the 1960s, the US museum economy was in free economy period. And the government offered little sponsorship. And major economic operations relied on private donations and private foundations. In the early 1960 s to 1980 s, the states were financially supported by government-set foundations. And it supported the funds to nonprofit institutions in the field of art through legislation. Generating revenue is also an important source of museum income. As early as 1908, the New York Metropolitan Museum began to have mail-order sales. In addition, it also built museum stores in some shopping centers and airports. Especially in the 1980s, the economic sources of museum relied on income-generating operations. And it mainly relied on tickets, membership fees, the income of art shops and restaurants. Also, it sold the collection of the museum, and it would have other activities to collect income. In addition, from the end of the 20th century to the present, the British, Dutch and Japanese museums have paid more attention to the study of the museum economy. And it has historical transformation of the symbolic creativity, text production and cultural industry in property rights and structure, cultural policy and regulation and communication technology. The financing, the market, and the development of cultural industries are also reflected in the evolution of the museum economy.

The domestic research began in the 1990s. There are many reasons for this. Firstly, the museum appeared in China later. Secondly, it paid attention to public welfare, and it has been ignoring its economic discussion since the establishment of the Chinese museum. After the founding of new China, the development of museum has been influenced by the Soviet museum business model. In China, museum economic research is accompanied with the establishment of the socialist market economic system. In the end of the 1980 s, many museum researchers had made articles on the economic benefits of the museum. And they had paid attention to the financial management and efficiency of the museum. In 1994, "Chinese Museum" published Liu Hong's article "On Museum Economics". And it is the first article to put forward the museum economics. In the 21 st century, with the deepening reform of the socialist market economy, it has paid more and more attention to cultural productivity. And the research on the museum economy has been increasing day by day. With multi-dimensional perspectives of the research, the construction of the museum economy presents multi-dimensional perspectives: cultural economics, tourism economics, welfare economics, management economics, and so on. As a branch of economics, the study of the museum economy plays a supporting role in the discipline. In addition, cultural industry, consuming culture and heritage economy, political economy and other research methods have also played a catalytic role in the museum economic research.

\section{COMPARISON OF DOMESTIC AND FOREIGN MUSEUM ECONOMY RESEARCH}

\section{A. The Status Quo of Foreign Museum Economy Research}

Museum was started in foreign countries. And it has a long history in the development process at abroad. Foreign 
research on the museum started earlier. And it also paid attention to the museum economic benefits relatively early. For the museum research, it has basically established a relatively complete discipline system. The cultural accumulation of foreign cultural and economic research is deep. However, the core contents of foreign cultural industries don't include museum. And the museum is an important carrier of cultural resources with the operating characteristics of cultural industry. The understanding of the cultural industry is deep. And the museum economic problems have become increasingly prominent. Foreign research on the museum economy is also close.

1) Discussion on the commercialization of the museum as a nonprofit organization: For a long time, the social functions of museum were in the first place. And it had completely obscured the economic attributes of museum. With the popularity of consuming culture, the consumption of spiritual products has become an important consumer area. And it has started to pay attention to the commodity attributes of museum. The commercial exploration of museum as a non-profit organization is the substantive study on museum economy ontology. In the United States, the commercialization of nonprofit organizations has attracted much attention. And the museum is the first to be concerned. In the past, the American museum relied on funding and public funds. And the tax exemption was also an important aspect of the museum economy. Recently, commercial models such as museum stores, online virtual stores, museum derivatives, and peripheral services have been popular in the United States. And it mainly aims for the limited commercialization of museums. In a mature market, the decision makers and cultural managers are still looking for ways to increase the museum's income. So, it may be experiencing the commercialization process in the US museum area [9].

2) The needs and supply of culture and art of museum: The cultural and artistic needs of the museum are important subjects of the museum economy research. From the late 1970 s to the early 1980 s, foreign museums began to pay attention to the consumer demand of the museum. The British Museum began to analyze the relationship between visitors and collections at the beginning of the 20th century. And the United States Metropolitan Museum paid attention to the service concept of customer care. The survey of public art and cultural needs is the work of cultural managers. And they should pay great concern to these works. There is no way to grasp the needs of products and visitors with the deficiency of necessary data.

3) Cultural heritage and tourism of museum: The experience sale of cultural heritage and tourism is a part of recent museum economy research. In these studies, it has shown that the museum's maximum satisfaction and intentions are the entertainment experience, and the second is the aesthetic experience and the escape of reality [10]. Museum is an important part of cultural tourism. The museum as the carrier of culture and tourism resources is developed and used from the international perspective. Some of the world's leading museums such as the French Louvre and other tourism projects as the supporting projects have brought comprehensive profits. In addition, the museum tourism is also concerned about the relationship between visitors and museums. There is realistic "ancestor" experience perception and cultural perception between visitors and cultural relics or buildings of museum. And this heritage tourism experience is museum cognitive experience with its unique characteristics. This kind of travel experience is the foundation of characteristic museum. Museum tourism industry is one of the important directions of museum economic development, is an important way to achieve the realization of the museum economy.

\section{B. The Status Quo of Domestic Museum Economy Research}

Compared with the foreign museum economic research, China's museum economic research started late. However, China's museum economic research has the advantages in the history. China's cultural tourism resources are rich. And the government pays much attention to the transformation and utilization of cultural tourism resources.

1) Discussion on the theoretical study of museum economy: Museum economic research is an important area of heritage economics. And cultural tourism resources with the characteristics of heritage economy stored in the museum. The economic value of the museum can be divided into direct use value and indirect use value from the use of categories. It can't deal with the cultural heritage of the museum. And the economic law of the production can't be used in the museum economy. It has been controversial to sell collections in foreign countries. And the practice is cumbersome and complex. It can't sale the museum collections as the products. However, the museum has product attribute. In Marx's spiritual consumption theory, it believes that the spirit consumption is the consumption activities to meet the spiritual needs. Human needs are divided into material needs and spiritual needs. Accordingly, human consumption can also be divided into material consumption and spiritual consumption [11]. The regional entities of museum (including the pavilion, architecture and collection environment) and the cultural qualities of museum are the spiritual products of the visitors' consumption. In the market economy, the values of products play a role through the circulation. And then, the products become commodity. Some scholars have classified the indirect value of the cultural heritage of the museum: the existence value, the option value and heritage value. And the total economic value, including the indirect use value, is often immeasurable in the actual market segment. In addition, cultural heritage has a strong value-added potential in the human history. In the cultural industry, the museum tourism is an important part of the tourism industry. And then, the museum is an important link of specific tourism experience. It has proposed to integrate the museum, 
tourism, culture and other industries to produce a new economic model according to the definition of the museum. The collection resources of museum are important objects of cultural and creative industries. The museum is the source of the cultural creativity of important artistic creation. The reality of the cultural tourism resources, the image and the cultural values are transferred through the authorization ways. It not only achieves the development of the museum economy, but also spreads the culture. Also, it achieves the cyclic economic development of the museum. Thus, the cost of the museum has reduced on the basis of the protection of the collection resources. And then, the income of the museum has increased. For example, with the Taipei Imperial Palace brand licensing strategy, the protagonist of the ancient painting "Painting of Children at Play" is accredited to the creative company, which designs the current popular toys. And it also develops a series of game works. And the Palace Museum has also developed many interesting products such as The King of Romance, the cards on the beats with the purpose of traveling and so on. In the process of theoretical and practical research on the museum economy, art authorization has been an important cultural and creative industry model, which is providing an important realization path for the transformation and utilization of cultural tourism resources.

2) Museum functions and policy regulation: The debate on the social and economic benefits of the museum has been the focus of museum functions and management. Due to the understanding of the market economy, the two functions of the museum are habitually placed on the opposite side. In the nature and function of the museum, China has established the concept "social benefits first, taking into account of other benefits". For many problems in the utilization of cultural tourism resources in recent years, there are newspapers publishing the article on the commercialization of cultural resources. The nature and function of the museum have always been clear. With the development of the market economy and the invasion of foreign culture, the re-understanding of cultural tourism resources is necessary. The cultural tourism resources of the museum are important cultural gene. And it is an important symbol of traditional culture. With the popularity of consuming culture, it has segregated the material ontology of cultural tourism resources of the museum from the value connotation. Then, it puts the cultural symbols of museum integrates into the cultural consumption areas. And it promotes the utilization of cultural tourism resources. Thus, the functions of the museum have new meanings in the national culture. And it obtains new meanings in the nonmaterial production areas. In addition, the development of museum policies is also an important factor affecting the development of the museum. In 2015, it developed the "Museum Regulations". And it suggests that the state encourages museum to tap the connotation of collections and combine them with cultural and creative industries and tourism industry to develop derivative products and enhance the development capability of museums. And it provides important policy for the cultural management of the museum.

3) Case study of the museum economy: The case study of the museum economy is a solution to the specific problems. At present, Chinese study of the museum economy is mainly concentrated in the following categories: the development case of museum tourism industry, the operation case of museum cluster, the operation case of the digitization of museum, the study on the audiences' experience of museum and other cases. And these case studies have the strong question directionality. At present, there are many studies on the development of the museum tourism industry. In essence, it has promoted or broadened the influence of the museum culture through the tourism industry with the museum and the derivative products as the carrier. The case study of the museum cluster is mainly the study of the museum location. Also, it refers to the research on museum tourism system (in addition to the buildings of museum, it also includes the regional nature, social and human environment). The study of museum community is based on the relative concentration of the location of museum as the geographical structure, tourism consumption and cultural consumption as the guide. And it has made the integrated design and development of the regional space. And then, it would achieve the development of museum in multi-format fields with the tourism as the core. The study of the digitization of museum is active. And the museum is in the digital protection and the current new media communication environment. The digitization of museum reflected in its economic research. And it is helpful to shape the image of the museum and brand marketing. The study on the museum's audience is the study on the museum's cultural and artistic demands. And it is an important basic research on the market orientation and self-characteristic of the museum. The study of the museum economy often provides important theoretical discussion for the construction of the museum economy. And it also can make the summary of the experience of the museum economic practice with Chinese characteristics.

\section{THE COMPARISON OF DOMESTIC AND FOREIGN MUSEUM ECONOMY AND ITS TREND AND CONSTRUCTION}

\section{A. Comparison: Similarities and Differences in Economic Research at Home and Abroad}

Due to the nature of the museum, the researches on museum have similarities. However, due to the different backgrounds of economic and political environment between China and the West, there are some differences in the study of the museum economy.

The controversy on the commercialization of museums is fierce at home and abroad. Compared with domestic studies, it develops the study of the commercialization of foreign museums with the decrease of fund input. They mainly 
debate two major issues. They are the museum ticket fees and the sale of collections. And the researchers mainly pay attention to the commercialization of museums and the important educational and research functions of museums. Due to the problems of the commercialization of nonprofit organizations, foreign scholars have constantly explored the degree and patterns of the commercialization problems. On the museum store and virtual museum and so on, most researchers' attitudes are positive. Domestic scholars argue about the property of the museum. The first attribute of social benefits seems to have rejected other benefits. And the concept of the commercialization of museum and museum economy has never been avoided. In the specific researches, they usually pay attention to the tourism, cultural industry and heritage economic value of the museum. However, the real problems are still the construction of the museum economy.

For the theory of museum economy, compared with foreign scholars, domestic scholars pay more attention to the theoretical basis of museum economy. The domestic scholars pay attention to the theory of cultural economics, the theory of inheritance economics, the tourism industry and cultural industry. They are the theoretical foundations. It is the study practice of domestic scholars. They often want to find the theoretical basis to go through the practice. In particular, the museum culture has the dual nature of culture and economy. And in the operation practice of socialist market economy, it has important premises of attribute and value judgment. And foreign market economy is mature. It also has many business operation models. There is no theoretical basis for the study of foreign museum economy. It should pay attention to the degree and mode of application of business model. Most of the case studies explore the commercialization of museum. And it searches for the balance between commercialization and social public consensus. Also, it pays attention to the direction of museum management. And it makes studies with the management or economic management knowledge.

\section{B. The Development Trend and Construction of Museum Economy Research}

Museum economic research is on the rational allocation of resources. The market economy has the greatest benefits. At the same time, the circulation configuration of resources is more in line with the foundation of the museum economy. And the center of museum economic research should pay attention to the utilization and allocation of cultural and educational resources. It should mobilize the vitality of cultural tourism resources of the museum. And then, the productivity of museum culture can play its role. The starting point and home of the museum's revenue-generating and economic operations should focus on the comprehensive benefits of museum protection, education, research, entertainment, cultural transmission and so on. The suits of tourism industry or an important output of cultural industry shouldn't avoid the popularity of consuming culture and cultural consumption in the current era. Museum economy is an important area of the heritage economy. The first is to play the value of the entity of museum resources. The second is to use the cultural symbols of museum to make it be an important element of consuming culture. And then, it would be an important part of cultural consumption.

\section{CONCLUSION}

Economic research on the development and utilization of museum should take care of the understanding and realization of the museum economy on the basis of the research ontology of museum economics. There are many questions that need to be studied in the field of museum economics.

- From the connotation and the objects of the museum economy to the museum operation and supply analysis on cultural service;

- From the theoretical basis of economics to the support of policy regulation;

- From the museum derivatives to the surrounding industries and tourism industry;

- From the management of economics to the marketing of digital museums;

- From the transformation of state-owned museums to the development of private museums;

- From the planning of cultural relics exhibition to the protection and use of intellectual property rights;

The construction of the museum economy is an important issue in the study of inheritance economics and cultural industry. And it is bound to promote the rational, full and comprehensive utilization of Chinese cultural tourism resources.

\section{REFERENCES}

[1] Kevin Moore.museum management[M].Routledge,1994

[2] Peter Johnson,Barry Thomas.The Economics of Museums:A Research Perspective[J].Journal of Cultural Economics, 1998(22):7585.

[3] Kenneth Hudson, Wang Jin. The rejection of museum to stop [J] Chinese Museum, 1998 (2): 33-37.

[4] Haier Buren, Gray. Translated by Zhan Zhengmao. Art and Culture Economics [M]. Beijing: Renmin University of China Press, 2007. 186-200.

[5] Liu Hong. On the museum economics [J]. Chinese Museum, 1994, (02): 24-36.

[6] Zeng Guangqing. A preliminary exploration of the museum economy [J]. Chinese Museum, 1999, (4): 14-17.

[7] Hu Zhaoyan. The ways of building the museum economy [N]. China Financial News, March 29, 2003 (3).

[8] Li Zuojun. Discussion on the theory and practice of museum economy [J]. Time Economy, 2012, (234): 52-58.

[9] Stefan Toepler, Sarah Dewees.Are there Limits to Financing Culture through the Market? Evidence from the US Museum Field [J]. Journal of Public Administration, 2005(28): 131-146.

[10] Laetitia Radder, Xiliang Han.An Examination Of The Museum Experience Based On Pine And Gilmore's Experience Economy Realms[J].The Journal of Applied Business Research,2015 (31):455-470.

[11] Karl Marx and Frederick Engels (Vol. 46, supra) [M]. Beijing: People's Publishing House, 1979. 